\title{
Smartphone Addiction, Fear of Missing Out, and Perceived Competence as Predictors of Social Media Addiction of Adolescents *
}

\author{
Aygul Tunc-Aksan \\ Ministry of Education, TURKEY
}

\author{
Sinem Evin Akbay ** \\ Mersin University, TURKEY
}

Received: February 20, 2019 - Revised: March 18, 2019 • Accepted: March 27, 2019

\begin{abstract}
In this study it is aimed to analyze the smartphone addiction, fear of missing out (FoM0), and perceived social and academic competence that predict social media addiction on high school students. Study group consists of 296 (136 females and 160 males) high school students studying in Anatolian High Schools and Vocational High School in Mersin during the 2017-2018 academic year. Simple random sampling was used. In the study, descriptive survey method was used. As data collection tools, Personal Information Form, Social Media Addiction Scale, Smartphone Addiction Scale, Fear of Missing Out Scale (FoM0), Perceived Competence Scale developed by Ozer et al. were used. In analyses of data, regression was used. According to stepwise regression analysis, smartphone addiction $(\beta=.34)$, fear of missing out $(\beta=.26)$ and perceived academic competence $(\beta=-.12)$ predict social media addiction level on high school students. As the result of the study, smartphone addiction, fear of missing out, and perceived academic competence predict social media addiction on high school students. When the smartphone addiction level and fear of missing out decrease, and also perceived academic competence improve, students' smartphone addiction levels reduce.
\end{abstract}

Keywords: Social media addiction, smartphone, fear of missing out, competence, adolescents

To cite this article: Tunc-Aksan, A., \& Akbay, S. E. (2019). Smartphone addiction, fear of missing out and perceived competence as predictors of social media addiction of adolescents. European Journal of Educational Research, 8(2), 559-566. doi: 10.12973/eujer.8.2.559

\section{Introduction}

In the last 25 years, technology has begun to be emphasized in the literature as a potential lead to addiction, as a result of the increasing online practices due to the rapid spread of technology. These studies that started with the concept of technological dependencies (Griffiths, 1995) began to be investigated under the roof of behavioral addictions such as sex, gambling, shopping, and eating (Griffiths, 2000; Petry, 2016). Griffiths, Kuss, and Demetrovics (2014) considered biopsychosocial view of the diagnostic criteria for behavioral addiction as distinctness, change of emotion, low tolerance, withdrawal symptoms, conflict and recurrence. In this context, it has been observed that social media addiction has long been involved in addiction-related literature (Griffiths, 2005; Kuss \& Griffiths, 2011). In the third section of the category of substance-related disorders and addiction disorders in the DSM-V (American Psychological Association [APA], 2013), which is the classification system of mental disorders of the American Psychological Association, it is seen that internet game playing disorder, which is proposed as a research topic, is included.

It is very difficult to define the widely used social media today. One of the most comprehensive definitions was made by McCay-Peet and Quan-Haas (2017). According to this definition, social media is a web-based service that allows individuals, communities and organizations to collaborate, connect, interact, and create communities through creating, re-creating, changing, sharing, and forming user-generated content. From a more technological point of view, social media is defined as an Internet-based group of applications that allow the creation of Web 2.0's intellectual and technological based and user-driven content and allowing mutual exchange (Kaplan \& Haenlein, 2010).

However, it is observed that social media and social networking sites are used interchangeably in studies. Social media includes social applications such as collaborative projects (e.g., Wikipedia), weblogs, content communities (e.g., YouTube), social networking sites, and virtual gaming and virtual social worlds (e.g., Second Life). Social networking sites, as part of social media, consist of virtual communities that connect people. The most popular social networking

\footnotetext{
* This study was presented as an oral presentation at the V. International Eurasian Educational Research Congress, May 02-05, 2018, Akdeniz University, Antalya, Turkiye.

** Corresponding author:

Sinem Evin Akbay, Department of Psychological Counseling and Guidance, Mersin University, Mersin / Turkey

$\bowtie$ sinemakbay@mersin.edu.tr
} 
sites include Facebook, Instagram, Snapchat, instant messaging providers like WhatsApp and Facebook Messenger, Twitter including Microblogs, and game sites like World of Warcraft (Kuss \& Griffiths, 2017).

Born in the digital world, today's adolescents are surrounded by computers, internet, video games, mobile phones or hand-held devices at home, at school, in other words, in every aspect of their lives. According to Subrahmanyam and Smahel, (2011), the digital world, like family, peer, and school, should be considered as another social context in adolescent development. Considering that usage of social media such as YouTube or Facebook is quite common among adolescents (Banyai et al.,2017; Lenhart, Purcel, Smith, \& Zickuhr, 2010). Social media practices among adolescents can cause them to be subjected for harmful effects and be at risk, as well as increase their likelihood of developing addiction (Alabi, 2013; Andreassen, Tosheim, Brunborg, \& Pallesen, 2012; Griffiths, Pontes, \& Kuss, 2016; Pelling \& White, 2009; Sofiah, Omar, Bolong, \& Osman, 2011; Wilson, Fornasier, \& White, 2010). As a result, while social media addiction has a negative effect on self-esteem and life satisfaction in adolescents, it also causes a decrease in academic performance, causes behavioural problems, and a decrease in social commitment. It is also related to Attention Deficit Hyperactivity Disorder (ADHD), anxiety disorders, and Obsessive-Compulsive Disorder (OCD) (Andreassen, et al., 2016; Banyai, et al., 2017; Hawi \& Samaha, 2016; Merelle, et al., 2017; Mingle, Adams, \& Adjei, 2016; Savci, Ercengiz, \& Aysan, 2017).

The studies on the reasons explaining the social media addiction that led to these results emphasize technology-related factors. Griffiths and colleagues, who work extensively on the definitions and causes of social media addiction in terms of digital addictions, emphasize that smartphone addiction and the "Fear of Missing Out" (FoMO) may be among the risk factors for social media addiction (Griffiths \& Kuss, 2017; Griffiths, et al., 2014).

When examined in this context, according to the 2018 data (Kemp, 2018), it is seen that 39\% of the world's population and $54 \%$ of Turkey's population are mobile social media users,. Considering that the use of social media is mostly carried out on mobile devices, it can be said that excessive use of smartphones may cause addictive behavior. For example, in a large sample study, Andreassen, et al. (2016) reported that access to social networking sites was mostly done by smartphones.

Fear of Missing Out (FoMO) is shown by different researchers as one of the reasons of social media addiction (Oberst, Wegmann, Stodt, Brand, \& Chamarro, 2017). FoMO is defined as being engaged with the need to stay on social networks in order not to miss something on the sites or the activities of others. In addition, FoMO consists of anxiety about others having rewarding activities while they are not on social networks (Przybylski, Murayama, DeHaan, \& Gladwell, 2013). The results of the study indicate that FoMO is related to the number of social media accounts and the frequency of controlling these accounts, in addition to being related to social media addiction (Hosgor, Koc-Tutuncu, GunduzHosgor, \& Tandogan, 2017).

On the other hand, from the perspective of adolescents, it is also seen that social media and social networks are defined as "a way to exist" (Griffiths \& Kuss, 2017). In this context, it has been tried to find out which personality traits affect addiction types in internet applications. These features emphasize, for example, that low self-esteem can create addiction on internet applications (Brand, Young, Laier, Wolfling, \& Potenza, 2016). According to the intrinsic motivation theory, the need for autonomy, the need for competence and the need to be in relationships are tried to be satisfied through social media use (Przybylski, Weinstein, Ryan, \& Rigby, 2009; Reinecke, Vorderer, \& Knop, 2014). Competence, which is amongst the developmental tasks during childhood and adolescence (McCormick, Kuo, \& Masten, 2011), consists of a general feeling that the person has capacity, is effective, and is in control (Tafarodi \& Swann, 1995). Perceived competence is usually defined on two dimensions, academic and social competence (Ozer, et al., 2016). Low levels of perceived competence naturally have a negative impact on the individuals (Tafarodi \& Swann, 2001). When viewed in the context of social media use, the low perception of competence affects having more information on social networking sites and making themselves more visible in social networks (Masur, Reinecke, Ziegele, \& Quiring, 2001). In addition, low social competence perception affects the overuse of social networking sites and/or the high use of Facebook (Satici, Saricali, Satici, \& Eraslan-Capan, 2014).

In the light of all these studies, the aim of this study is to explain the reasons of social media addiction, through the variables of smartphone addiction, the fear of missing out and the perceived academic and social competencies in high school students. In this direction, the answers to the following questions were sought:

1. Does the smartphone addiction, social competence perception and academic competence perception of high school students predict social media addictions?

2. What is the power of the variables of smartphone addiction, social competence perception and academic competence perception in predicting social media addiction?

\section{Methodology}

\section{Design}

In this study, correlational research model was used to investigate the predictors of social media addiction on high school students. 
Sample

The research group consisted of 296 (136 females and 160 males) students attending Anatolian High Schools and Vocational High Schools in Mersin in the 2017-2018 academic year. Simple random sampling method was used in the study. Demographic data of the students participating in the study are shown in Table 1.

Table 1. Demographic Data of Participants

\begin{tabular}{|c|c|c|c|}
\hline & Demographic Features & f & $(\%)$ \\
\hline \multirow{3}{*}{ Gender } & Female & 136 & 45,9 \\
\hline & Male & 160 & 54,1 \\
\hline & Total & 296 & 100,0 \\
\hline \multirow{5}{*}{ Grade } & 9th Grade & 72 & 24,3 \\
\hline & 10th Grade & 88 & 29,7 \\
\hline & 11th Grade & 64 & 21,6 \\
\hline & 12th Grade & 72 & 24,3 \\
\hline & Total & 296 & 100,0 \\
\hline \multirow{8}{*}{ Mother's Education } & Untutored & 16 & 5,4 \\
\hline & Literate & 10 & 3,4 \\
\hline & Primary school & 84 & 28,4 \\
\hline & Middle school & 57 & 19,3 \\
\hline & High school & 87 & 29,4 \\
\hline & University & 41 & 13,9 \\
\hline & Graduate & 1 & ,3 \\
\hline & Total & 296 & 100,0 \\
\hline \multirow{8}{*}{ Father's Education } & Untutored & 11 & 3,8 \\
\hline & Literate & 5 & 1,7 \\
\hline & Primary school & 57 & 19,3 \\
\hline & Middle school & 64 & 21,6 \\
\hline & High school & 89 & 30,1 \\
\hline & University & 63 & 21,3 \\
\hline & Graduate & 7 & 2,4 \\
\hline & Total & 296 & 100,0 \\
\hline \multirow{3}{*}{$\begin{array}{l}\text { Having a } \\
\text { Smartphone }\end{array}$} & Yes & 296 & 100,0 \\
\hline & No & $\mathbf{0}$ & 0,0 \\
\hline & Total & 296 & 100,0 \\
\hline \multirow{7}{*}{$\begin{array}{l}\text { The purpose of using } \\
\text { Smartphone }\end{array}$} & Calling & 98 & 33,1 \\
\hline & Sms & 12 & 4,1 \\
\hline & E-mail & 2 &, 7 \\
\hline & Surf & 49 & 16,6 \\
\hline & Social media & 131 & 44,3 \\
\hline & Taking photo & 4 & 1,4 \\
\hline & Total & 296 & 100,0 \\
\hline \multirow{5}{*}{$\begin{array}{l}\text { Period of using } \\
\text { Smartphone }\end{array}$} & 1 hour & 93 & 31,4 \\
\hline & 2 hours & 95 & 32,1 \\
\hline & 3 hours & 48 & 16,2 \\
\hline & 4 hours and above & 60 & 20,3 \\
\hline & Total & 296 & 100,0 \\
\hline
\end{tabular}

Instruments

Personal Information Form. A personal information form was prepared to determine the demographic characteristics of the participants.

Social Media Addiction Scale (SMAS). The scale was developed by van den Eijnden, Lemmens, and Valkenburg (2016). The scale consisting of one dimension was developed by taking the Internet Game Addiction criteria in DSM-V into account. The scale consisted of 9 items and is answered as "Yes" and "No". The cut-off point was chosen as 5, in the scale where the scoring was between 0 and 9. Cronbach Alpha internal consistency coefficient of the scale was obtained as .82. The Cronbach's alpha coefficient of internal consistency of the scale adapted to Turkish by Tas (2017), was determined to be .76. In this study, it was obtained as .74. 
Smartphone Addiction Scale (SAS). The scale was developed by Kwon et al. (2013). The self-evaluation scale that measures addiction to smartphones, consists of six dimensions. The scale with six-point Likert scale consisted of 33 items and the high scores from the scale were defined as serious phone addiction. The dimensions of the scale were composed of daily life disorders, positive expectations, feeling of withdrawal, virtual oriented relationship, excessive use, and dependence. The Cronbach Alpha internal consistency coefficient was 0.97 and 0.86, .91, .88, .0.90, .83, .0.87 for each sub-dimension, respectively. The fit index values of the scale, adapted to Turkish by Sata, Celik, Erturk and Tas (2016), were found as RMSEA=.058, GFI=.84, $\mathrm{AGFI}=.82$, $\mathrm{NNFI}=.96, \mathrm{CFI}=.96$ according to the confirmatory factor analysis results. The internal consistency coefficient for the entire scale was .94 and the internal consistency coefficients obtained for all dimensions ranged from .72 to .84 . The Cronbach Alpha internal consistency coefficient was found to be .92 for this study.

Fear of Missing Out Scale (FoMO). The scale was developed by Przybylski, et al. (2013) consisted of 10 questions. The scores obtained from the five-point Likert-type scale varied between 10 and 50, and it was assumed that the individual's fear of missing out was higher as the score from the scale increased. The Cronbach alpha coefficient of the scale, adapted to Turkish by Gokler, Aydin, Unal and Metintas (2016), was obtained as 0.81, and test-retest reliability coefficient was obtained as 0.81 . In this study, Cronbach alpha coefficient was obtained as .81.

Perceived Competence Scale (PCS). The scale was developed by Ozer, et al. (2016), which evaluates the perceptions of adolescents towards themselves, consisted of academic competence and social competence dimensions. The scale consisting of 30 items was a five-point Likert-type scale. The development of the scale was carried out with three different high school student samples. In the light of these studies, internal consistency (Cronbach $\alpha$ ) coefficients were obtained as .90 - .93 for the academic competence dimension and .82 - .86 for the social competence dimension, respectively. The internal consistency (stratified $\alpha$ ) coefficient for the entire scale was .91, and the corrected correlation coefficients (r) for test-retest reliability were .94 for social competence and .90 for academic competence. For this study, the Cronbach alpha for the social competence dimension was measured as .92 and the Cronbach alpha for the academic competence dimension was measured as .83 .

\section{Analyzing the Data}

In the analyses of data, firstly, multiple regression analysis requirements were examined. For this purpose, first of all, if the scales were normally distributed, then a linear relationship between predictive variables and predicted variables SPSS program was examined by scattering diagram. After that, considering the Mahalanobis test results, Pearson Correlation Coefficients were calculated. Finally, multiple regression analysis and stepwise regression analysis were used to determine whether the independent variables predicted the dependent variable, and how strongly predicted the dependent variable. All data were tested at .05 significance level.

\section{Findings/Results}

In this section, the results of the correlation and gradual regression analysis between social media addiction and smartphone addiction, fear of missing out, social competence perception and academic competence perception are given.

Table 2 shows the findings related to the correlation coefficients between social media addiction, smartphone addiction, fear of missing out, social competence perception and academic competence perception.

Table 2. Correlation coefficients between social media addiction, fear of missing out, social competence perception, academic proficiency perception and smartphone addiction in high school students

\begin{tabular}{|c|c|c|c|c|c|}
\hline & 1 & 2 & 3 & 4 & 5 \\
\hline 1. SMAS-KF & 1 & & & & \\
\hline 2. FoMOS &, $430\left(^{* *}\right)$ & 1 & & & \\
\hline 3. PCS-SCP & $-110\left(^{*}\right)$ & ,050 & 1 & & \\
\hline 4. PCS-ACP &,$- 243\left(^{* *}\right)$ &,- 106 &, $531(* *)$ & 1 & \\
\hline 5. SPAS &, $492\left({ }^{* *}\right)$ &, $422(* *)$ & -109 &,$- 250(* *)$ & 1 \\
\hline Mean & 2,29 & 22,79 & 55,56 & 56,97 & 89,20 \\
\hline SD & 2,17 & 7,6 & 9,97 & 12 & 27,287 \\
\hline$\alpha$ & .74 & .92 & .81 & .92 & .83 \\
\hline
\end{tabular}

Competence Scale-Social Competence Perception, PCS-ACP: Perceived Competence Scale-Academic Competence Perception, SPAS: Smartphone Addiction Scale

For the 296 high school students, constituting the total sample, when the correlation coefficients between the predicted variable of social media addiction and predicting variables (smartphone addiction, fear of missing out, perception of social competence and perception of academic competence) are examined; while there was a significant positive correlation between social media addiction and smartphone addiction $(r=.48, p<.001)$ and the fear of missing out $(r=$ 
$.41, \mathrm{p}<.001$ ), there was a significant negative relationship between social media addiction and perceived social competence $(\mathrm{r}=-.12, \mathrm{p}<.001)$ and perceived academic competence $(\mathrm{r}=-.23, \mathrm{p}<.001)$. According to these findings, adolescents' addiction to smartphones and their fear of missing out increases, their social media addiction increases. In addition, as their perceived social and academic competence decreases, their addiction to social media also increases.

Table 3 presents the results of multiple regression analysis for smartphone addiction, fear of missing out, social competence perception and academic competence perception in predicting social media addiction scores of students'.

Table 3. Results of multiple regression analysis regarding social media addiction, smart phone addiction, fear of missing out, social competence perception and academic competence perception in high school students

\begin{tabular}{lccccc}
\hline Variables & $\mathbf{B}$ & $\mathbf{S H}_{\mathbf{B}}$ & $\boldsymbol{\beta}$ & $\mathbf{t}$ & $\mathbf{p}$ \\
\hline 1. Constant &,- 244 &, 822 & &,- 297 &, 767 \\
2. FoMOS &, 075 &, 015 &, 261 & 4,821 &, 000 \\
3. PCS-SCP &,- 011 &, 013 &,- 048 &,- 842 &, 400 \\
4. PCS-ACP &,- 018 &, 011 &,- 097 & $-1,657$ &, 001 \\
5. SPAS &, 027 &, 004 &, 342 & 6,216 &, 000 \\
\hline
\end{tabular}

${ }^{*} \mathrm{p}<.01$

When the results of the regression analysis were examined, it was observed that smart phone addiction, fear of missing out, and perceived academic competence predicted social media addiction $(\mathrm{F}(4-291)=30.751, \mathrm{p}<.001)$. However, perceived social competence did not predict social media addiction. According to this result, all variables except the perceived social competence, predicted $30 \%$ of adolescents' social media addiction scores.

In addition to these results, a stepwise regression analysis was performed in order to see the unique effect of each variable of smartphone addiction, fear of missing out, and perceived academic competence on the social media addiction variable, in addition to seeing their combined effect. The results of the analysis are presented in Table 4.

Table 4. Gradual regression analysis results related to social media addiction, smart phone addiction, fear of missing out, social competence perception and academic competence perception in high school students

\begin{tabular}{clllllllll}
\hline Model & Variables & $\mathbf{B}$ & $\mathbf{S H}_{\mathbf{B}}$ & $\boldsymbol{\beta}$ & $\mathbf{t}$ & $\mathbf{R}$ & $\mathbf{R}^{2}$ & $\mathbf{F}$ & $\mathbf{p}$ \\
\hline $\mathbf{1}$ & Constant & $-1,083$ &, 382 & & $-2,836$ & & & & \\
& SPAS &, 038 &, 004 &, 475 & 9,257 &, 475 &, 226 & 85,684 &, 000 \\
\hline \multirow{2}{*}{$\mathbf{2}$} & Constant & $-2,022$ &, 418 & & $-4,840$ & & & & \\
& SPAS &, 030 &, 004 &, 371 & 6,862 &, 530 &, 281 & 57,355 &, 000 \\
& FoMOS &, 074 &, 015 &, 258 & 4,765 & & & & \\
& Constant &,- 547 &, 739 & &,- 740 & & & \\
& SPAS &, 027 &, 004 &, 343 & 6,254 & \multirow{2}{*}{, 544} &, 295 & 40,806 &, 000 \\
$\mathbf{3}$ & FoMOS &, 073 &, 015 &, 255 & 4,754 & & & & \\
& PCS-ACP &,- 022 &, 009 &,- 122 & $-2,413$ & & & & \\
\hline
\end{tabular}

$* \mathrm{p}<.01$

As a result of gradual regression analysis, the variables of smartphone addiction ( $\beta=.34$ ), fear of missing out $(\beta=.26)$ and perceived academic competence $(\beta=-.12)$ variables significantly predicted adolescents' social media dependencies $(\mathrm{F}(3-292)=40.806, \mathrm{p}<.001)$. According to the findings, smartphone addiction accounts for $23 \%$ of the total variance as the most important predictor of social media addictions of adolescents. The variables of smartphone addiction and fear of missing out combined explained $28 \%$ of the total variance. Smartphone addiction, fear of missing out and perceived academic competence variables accounted for $30 \%$ of adolescents' social media addiction $(\mathrm{R}=.544, \mathrm{R} 2=.295)$.

\section{Discussion and Conclusion}

In this study, the factors explaining the social media addiction of adolescents were tried to be explained through smartphone addiction, fear of missing out, and perceived competence. The results of the study showed that the first cause of social media addiction among adolescents was smartphone addiction. This result of the study is in parallel with the literature (Kwon, et al., 2013; Mohammadi, et al., 2018; Park, 2005). While discussing whether overuse of smartphones will be included in a category of behavioral addictions, the results of this study has a quality describing smartphone addiction, similar to other studies (Billieux, Maurage, Lopez-Fernandez, Kuss, \& Griffiths, 2015; Kuss \& Griffiths, 2017; Salehan \& Negahban, 2013). However, addiction patterns of smartphones can be claimed to originate from applications such as calling, messaging, or social networking sites on smartphones (Kuss \& Griffiths, 2017).

Another finding of the study is the fear of missing out, which was the second variable predicting social media addiction among adolescents. Although it is a fairly new concept, the results of these studies showed that the fear of missing out among adolescents affected the use of problematic social media use. For example, a study conducted on 3000 adolescents reported that the use of problematic social networking sites is affected by the fear of missing out (van den 
Abeele \& van Rooij, 2016). In addition to these findings, a study with 5280 adolescents had similar findings (Oberst, et al., 2017). With this study, fear of missing out, which is proved to be common among university students in Turkey (Hosgor, et al., 2017), has also been proven to be an important factor in influencing the social media addiction in high school students.

The other finding of this study was that the perception of academic competence among adolescents was the third variable predicting social media addiction. In other words, adolescents who perceived themselves as academically competent had less risk of developing social media addiction. Academic competence as a perception of cognitive competence, consisted of the ability to do their homework, to answer questions, to finish school assignments and the child feeling intelligent (Harter, 1988). Adolescents who find themselves competent in academic terms, affect their personal and social development and protect themselves from various negative situations (Ozer, et al., 2016).

Although the relationship between social media addiction and social competence perception is emphasized in the literature (Satici, et al., 2014), in this study there was a negative and low relationship between social media addiction and social competence, and it was seen that social competence perception did not explain social media addiction. It was expected and desirable to have a high level of competence in a social context (Sheldon, Ryan, \& Reis, 1996). As a social entity, having a high belief in social competence can be considered as a basic need for humans. Based on this need, social media can be seen as an environment where an individual who does not feel competent in a social sense can express themselves better in order to provide this sense of competence (Hoffman \& Novak, March, 2013). In this study, it was possible that the social competence perception did not predict social media addiction, because the sample saw themselves as competent in the social context $(X=55,56)$ and was not addicted to social media $(X=2,29)$.

In the light of these results, it can be seen how prevention of social media addiction among adolescents can be carried out by smartphone usage explanation and social media literacy. In addition, studies aimed at increasing students' perceptions of academic competence will be effective in preventing social media addiction.

As a conclusion, social media addiction has been became an issue of concern, especially on young people, on the literature. Although it is still not considered as a disorder in a DSM-V, research results show that heavy social media usage is very common and has negative effect on among young people. In the present study, it was aimed to expand the literature risk and protective factors on social media addiction on young people's lives. The findings of the study showed that the most important risk factor for social media addiction was smartphone addiction on adolescents. The study results showed that the second risk factor for social media addiction was fear of missing out. As a protective factor, the high level perceived academic competence was found. Therefore, developing programs for healthy usage of smartphone for both parents and adolescents can be appropriate strategy for prevention. Also, assessment of risk groups for smartphone addicted adolescents is another good strategy for remedial programs. Additionally, increasing the programs including social activities, and teaching effective and efficient learning methods for students in schools can be effective on reducing unhealthy social media usage among adolescents.

As limitations, in the present study some personality characters of adolescents was not taken into consideration for risk factors. Next studies can be focus on personality variables to find out risk factors for social media addiction. Also, the sample of the study was low for generalizability of the results. Like other studies (e.g., Andreassen, et al., 2016; Banyai, et al., 2017), a large-scale studies can be held for finding out profile of adolescents social media usage and risk and protective factors.

\section{References}

American Psychiatric Association, DSM-5 Task Force. (2013). Diagnostic and statistical manual of mental disorders (5th ed.). Arlington, VA: American Psychiatric Publishing.

Alabi, O. F. (2013). A survey of Facebook addiction level among selected Nigerian university undergraduates. New Media and Mass Communication, 10, 70-80.

Andreassen, C. S., Tosheim, T., Brunborg, G. S., \& Pallesen, S. (2012). Development of a Facebook book addiction scale. Psychological Reports, 110(2), 501-517.

Andreassen, C. S., Billieux, J., Griffiths, M. D., Kuss, D. J., Demetrovics, Z., Mazzoni, E., \& Pallesen, S. (2016). The relationship between addictive use of social media and video games and symptoms of psychiatric disorders: A largescale cross-sectional study. Psychology of Addictive Behaviors, 30(2), 252-262. doi: 10.1037/adb0000160

Banyai, F., Zsila, A., Kiraly, O., Maraz, A., Elekes, Z., Griffiths, M., ... Demetrovics, Z. (2017). Problematic social media use: Results from a large-scale nationally representative adolescent sample. PLOS ONE, 12(1), e0169839. doi: 10.1371/journal.pone.0169839

Billieux, J., Maurage, P., Lopez-Fernandez, O., Kuss, D. J., \& Griffiths, M. D. (2015). Can disordered mobile phone use be considered a behavioral addiction? An update on current evidence and a comprehensive model for future research. Current Addiction Reports, 2(2), 156-162. 
Brand, M., Young, K. S., Laier, C., Wolfling, K., \& Potenza, M. N. (2016). Integrating psychological and neurobiological considerations regarding the development and maintenance of specific Internet-use disorders: An Interaction of Person-Affect-Cognition-Execution (I-PACE) model. Neuroscience \& Biobehavioral Reviews, 71, 252-266.

Gokler, M. E., Aydin, R., Unal, E., \& Metintas, S. (2016). Sosyal ortamlarda gelismeleri kacirma korkusu olceginin Turkce surumunun gecerlilik ve guvenilirliginin degerlendirilmesi [Determining validity and reliability of Turkish version of Fear of Missing out Scale]. Anatolian Journal of Psychiatry, 17(Suppl.1), 53-59.

Griffiths, M. D. (1995). Technological addictions. Clinical Psychology Forum, 76, 14-19.

Griffiths, M. D. (2000). Does Internet and computer "addiction" exist? Some case study evidence. Cyberpsychology \& Behavior, 3(2), 211-218.

Griffiths, M. D. (2005). A “components" model of addiction within a biopsychosocial framework. Journal of Substance Use, 10(4), 191-197.

Griffiths, M. D., Pontes, H. M., \& Kuss, D. J. (2016). Online addictions: Conceptualizations, debates, and controversies. Addicta: The Turkish Journal on Addictions, 3(2), 151-164.

Griffiths, M., \& Kuss, D. J. (2017). Adolescent social media addiction (revisited). Education and Health, 35(3), 49-52.

Griffiths, M., Kuss, D. J., \& Demetrovics, Z. (2014). Social networking addiction: An overview of preliminary findings. In K. Rosenberg \& L. Feder (Eds.), Behavioral Addictions: Criteria, Evidence, and Treatment (119-141.). New York, NY: Elsevier.

Harter, S. (2012). Self-perception profile for adolescents: Manual and questionnaires. Retrieved from https://portfolio.du.edu/SusanHarter/page/44210

Hawi, N. S., \& Samaha, M. (2016). To excel or not to excel: Strong evidence on the adverse effect of smartphone addiction on academic performance. Computers \& Education, 98, 81-89. doi: 10.1016/j.compedu.2016.03.007

Hoffman, D. L., \& Novak, T. (2013). Online experience in social media: Two paths to feeling close and connected. Retrieved from https://papers.ssrn.com/sol3/papers.cfm?abstract_id=1990005

Hosgor, H., Koc-Tutuncu, S., Gunduz-Hosgor, D., \& Tandogan, O. (2017). Universite ogrencileri arasinda sosyal medyadaki gelismeleri kacirma korkusu yayginliginin farkli degiskenler acisindan incelenmesi [Examination in terms of different variables of prevalence of fear of missing out among college students]. Journal of Academic Value Studies, 3(17), 213-223.

Kaplan, A. M., \& Haenlein, M. (2010). Users of the world, unite! The challenges and opportunities of Social Media. Business Horizons, 53(1), 59-68.

Kemp, S. (2018). Digital in 2018: World's internet users pass the 4 billion mark. Retrieved from https://wearesocial.com/blog/2018/01/global-digital-report-2018.

Kuss, D. J., \& Griffiths, M. D. (2011). Online social networking and addiction - A review of the psychological literature. International Journal of Environmental Research and Public Health, 8(9), 3528-3552.

Kuss, D. J., \& Griffiths, M. D. (2017). Social networking sites and addiction: Ten lessons learned. International Journal of Environmental Research and Public Health, 14(3), 1-17.

Kwon, M., Lee, J., Won, W., Park, J., Min, J., Hahn, ... Kim, D. (2013). Development and validation of a smartphone addiction scale (SAS). PLOS ONE, 8(2), 1-7.

Lenhart, A., Purcell, K., Smith, A., \& Zickuhr, K. (2010). Social media \& mobile Internet use among teens and young adults. Retrieved from http://pewinternet.org/Reports/2010/Social-Media-and-Young-Adults.aspx

Masur, P. K., Reinecke, L., Ziegele, M., \& Quiring, O. (2001). The interplay of intrinsic need satisfaction and Facebook specific motives in explaining addictive behavior on Facebook. Computers in Human Behavior, 39, $376-386$.

McCay-Peet, L., \& Quan-Haase, A. (2016). What is social media and what questions can social media research help us answer? In L. Sloan, \& A. Quan-Haase (Eds.), The SAGE Handbook of Social Media Research Methods (pp. 13-26). London, UK: SAGE.

McCormick, C. M., Kuo, S. I-C., \& Masten, A. S. (2011). Developmental tasks across the lifespan. In K. L. Fingerman, C. A. Berg, J. Smith, \& T. C. Antonucci (Eds.), Handbook of lifespan development (pp. 117-140). New York, NY: Springer.

Merelle, S. Y. M., Kleiboer, A. M., Schotanus, M., Cluitmans, T. L. M., Waardenburg, C. M., Kramer, D. van de Mheen, D., \& van Rooij, A. J. (2017). Which health-related problems are associated with problematic video-gaming or social media use in adolescents? A large-scale cross-sectional study. Clinical Neuropsychiatry: Journal of Treatment Evaluation, 14(1), 11-19.

Mingle, J., Adams, M., \& Adjei, E. A. (2016). A comparative analysis of social media usage and academic performance in public and private senior high schools. Journal of Education and Practice, 7(7), 13-22. 
Mohammadi, S., Valinejadi, A., Saman, J. A., Karimpour, H., Kaivanfar, M., Safaeipour, M., Mohammadi, A., \& Kawyannejad, R. (2018). Assessment of addiction to internet, smartphone and social networks among students of medical sciences: A cross sectional study. Electronic Journal of General Medicine, 15(4), 1-8.

Oberst, U., Wegmann, E., Stodt, B., Brand, M., \& Chamarro, A. (2017). Negative consequences from heavy social networking in adolescents: The mediating role of fear of missing out. Journal of Adolescence, 55, 51-60.

Ozer, A., Genctanirim Kurt, D., Kizildag, S., Demirtas Zorbaz, S., Arici, F., Acar, T., \& Ergene, T. (2016). Ergenler icin yeterlik algisi olceginin (YAO) gelistirilmesi [Developing perceived competence scale (PCS) for adolescents]. Journal of Measurement and Evaluation in Education and Psychology, 7(1), 237-250.

Park, W. K. (2005). Mobile phone addiction. In R. Ling, \& P. Pedersen (Eds.), Mobile Communications: Re-negotiation of the Social Sphere (pp. 253-272). London, UK: Springer.

Pelling, E., \& White, K. M. (2009). The theory of planned behaviour applied to young people's use of social networking Web sites. Cyberpsychology \& Behavior, 12(6), 755-759.

Petry, N. M. (2016). Introduction to behavioral addictions. In N. M. Petry (Ed.), Behavioral Addictions DSM-5 and Beyond (pp. 1-7). Oxford, UK: Oxford University Press.

Przybylski, A. K., Murayama, K., DeHaan, C. R., \& Gladwell, V. (2013). Motivational, emotional, and behavioral correlates of fear of missing out. Computers in Human Behavior, 29(4), 1841-1848.

Przybylski, A. K., Weinstein, N., Ryan, R. M., \& Rigby, C. S. (2009). Having to versus wanting to play: Background and consequences of harmonious versus obsessive engagement in video games. Cyberpsychology \& Behavior, 12(5), 485492.

Reinecke, L., Vorderer, P., \& Knop, K. (2014). Entertainment 2.0? The role of intrinsic and extrinsic need satisfaction for the enjoyment of Facebook use. Journal of Communication, 64(3), 417-438.

Salehan, M., \& Negahban, A. (2013). Social networking on smartphones: When mobile phones become addictive. Computers in Human Behavior, 29(6), 2632-2639.

Satici, B., Saricali, M., Satici, S. A., \& Eraslan, C. B. (2014). Social competence and psychological vulnerability as predictors of Facebook addiction. Studia Psychologica, 56(4), 301-308.

Savci, M., Ercengiz, M., \& Aysan, F. (2018). Turkish adaptation of the Social Media Disorder Scale in adolescents. Noro Psikiyatri Arsivi, 55(3), 248-255.

Sheldon, K. M., Ryan, R., \& Reis, H. T. (1996). What makes for a good day? Competence and autonomy in the day and in the person. Personality and Social Psychology Bulletin, 22(12), 1270-1279.

Sofiah, S., Omar, S. Z., Bolong, J., \& Osman, M. N. (2011). Facebook addiction among female university students. Revista De Administratie Publica Si Politici Sociale, 2(7), 95-109.

Subrahmanyam, K., \& Smahel, D. (2011). Digital youth: The role of media in development. New York, NY: Springer.

Sata, M., Celik, I., Erturk, Z., \& Tas, E. U. (2016). Akilli telefon bagimliligi olcegi'nin (ATBO) Turk lise ogrencileri icin uyarlama calismasi [The study of adapting Smartphone Addiction Scale (SAS) for Turkish high school students]. Journal of Measurement and Evaluation in Education and Psychology, 7(1), 156-169.

Tafarodi, R. W., \& Swann, W. B. (1995). Self-liking and self-competence as dimensions of global self-esteem: Initial validation of a measure. Journal of Personality Assessment, 65(2), 322-342.

Tafarodi, R. W., \& Swann, W. B. (2001). Two-dimensional self-esteem: Theory and measurement. Personality and Individual Differences, 31(5), 653-673.

Tas, I. (2017). Ergenler icin Sosyal Medya Bagimliligi Olcegi Kisa Formunun (SMBO-KF) gecerlik ve guvenirlik calismasi [The study of validity and reliability of the Social Media Addiction Scale Short Form for adolescents]. Online Journal of Technology Addiction \& Cyberbullying, 4(1), 27-40.

van den Eijnden, R. J. J. M., Lemmens, J. S., \& Valkenburg, P. M. (2016). The social media disorder scale. Computers in Human Behavior, 61, 478-487. doi: 10.1016/j.chb.2016.03.038

Vanden Abeele, M., \& van Rooij, T. (2016). Fear of missing out (FOMO) as a predictor of problematic social media use among teenagers. International Conference on Behavioral Addictions, Abstracts. Presented at the International Conference on Behavioral Addictions.

Wilson, K., Fornasier, S., \& White, K. M. (2010). Psychological predictors of young adults' use of social networking sites. Cyberpsychology, Behavior, and Social Networking, 13(2), 173-177. 